\title{
The Impact of Operating Parameters and System Architecture on the Water Management of a Multifunctional PEMFC System
}

\author{
Claudia Werner ${ }^{* \dagger}$, Lucas Busemeyer ${ }^{\dagger}$, Josef Kallo \\ German Aerospace Center, Institute of Engineering Thermodynamics, Germany
}

\begin{abstract}
The focus of this paper is on multifunctional PEMFC application considering the products electric power and oxygen depleted air (ODA) to be used in aviation. Presented are operation and architecture analyses of a PEMFC system (HyPM XR 12) based on process simulations as well as experimental investigations. The effects of the stack temperature $\left(20-90^{\circ} \mathrm{C}\right)$, the operating pressure $(0.2-2.0$ bar $)$ and the cathode stoichiometric ratio $(1.0-5.0)$ on the resulting average relative humidity of the cathode exhaust gas and consequently on the efficiency and stability are evaluated for a single and a highly innovative twin system (serial cathode including an interim condensation process).

The results achieved are used to identify operation and architecture improvements for an appropriate water management, a key aspect to optimize efficiency and stability of PEMFC systems [1]. Based on the process simulation and experimental investigations can be summarized: In single and twin system operation the stack temperature and the cathode stoichiometric ratio have to be decreased at reduced operating pressure to avoid membrane dehydration. An additional feed gas humidification could be appropriate, especially at low pressure operation. The twin system architecture is relevant to minimize fuel cell flooding at high operating pressure and low stoichiometric ratios required to achieve ODA specifications.
\end{abstract}

Keywords: PEMFC, water management, membrane humidification, oxygen concentration, efficiency, aviation

* Corresponding author. Tel.:+49-40-743-55295,

Fax: +49-40-743-74727, E-mail address: claudia.werner@dlr.de

${ }^{\dagger}$ Equal contributors

\section{Introduction}

The application of PEMFC systems in aviation is an option to meet the ACARE VISION 2020 [2]. The specific mode of operation and architecture of the fuel cell system result from the designated use in aircrafts defining the requested requirements. This paper refers to the multifunctional use of PEMFC systems, including the supply of electrical power and oxygen depleted air for tank and cargo inerting and/or fire suppression and fire fighting in particular. Requirements to be considered for these applications are related to the PEMFC systems themselves, especially in terms of water management affected by operating pressure, stack temperature and cathode stoichiometric ratio variations relevant in aviation.

An adequate membrane humidification is highly required for a high-performing and steady PEMFC operation. A shortage in membrane humidity affects the $\mathrm{H}^{+}$proton 
conduction and decreases the fuel cell efficiency. A surplus of water at the cathode results in condensation of water, blocking the active catalyst surface and decreasing the fuel cell efficiency, consequently. Thus, the key challenge in PEMFC operation is the adjustment of the optimal membrane humidity, called water management [3] Generally, a PEMFC operation without external humidification is feasible and desirable due to the gradual reduction of system complexity. In such a case only the product water generated in the electrochemical reaction is available for membrane humidification. For this reason an effective water management is important [4]. The water balance inside the PEMFC is affected by different parameters. System parameters, such as flow field design, membrane type, membrane thickness or type of gas diffusion layer and operating parameters, such as cathode stoichiometric ratio, stack temperature or operating pressure are to be distinguished [5 - 6]. Specific modifications of the resulting relative humidity of the cathode exhaust gas and consequently the membrane humidification itself are to be realized by the adjustment of the operating parameters mentioned above [7 - 9]. A highperforming and steady PEMFC operation requires a relative humidity of about $100 \%$ at the outlet of the cathode, as described in [10 - 11]. This region is variable to some extent by modifications of system components, such as membrane type, membrane thickness or type of gas diffusion layer [11] and/or flow field design. A HyPM XR 12 (Hydrogenics, Corp., Canada) system characterized by an optimal relative humidity of the cathode exhaust gas of about $100 \%$ (factory settings) is considered in this paper. The optimal operating conditions have to be identified for this PEMFC system in aviation application to implement a control for an appropriate water management of the particular fuel cell system architecture, as discussed in the following sections.

\section{Experiments and procedures}

This section describes the experiments and procedures applied to characterize the impact of operating parameters and system architecture on the water management of a multifunctional PEMFC system. Considered are the modelling and simulation as well as the experimental setup.

\subsection{Modelling and Simulation}

The process simulation is focused on analysis of operating parameters (stack temperature, operating pressure and cathode stoichiometric ratio) and system architectures in terms of the water management in a multifunctional PEMFC system to be applied in aviation applications.

The water management influenced significantly by the relative humidity $(\mathrm{rH})$ of the cathode exhaust gas affects the efficiency and stability of the PEMFC system [3]. Moreover, the oxygen content of the exhaust gas (cathode) is an issue in the multifunctional fuel cell operation. Both output parameters depending on the fuel cell system architecture are to be calculated. Two fuel cell system architectures are considered, viz. a single and an advanced twin system. The single system is realized without any inlet gas humidification as illustrated in Fig. 1a. The advanced twin system shown in Fig. 1b contains two fuel cell systems. The cathodes of both systems are connected in series. An interim gas conditioning process (condenser, separator) is included to control the inlet parameters of the second fuel cell system. The second fuel cell is supplied by the conditioned exhaust air of the first fuel cell.

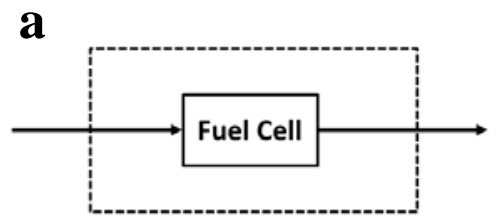

b

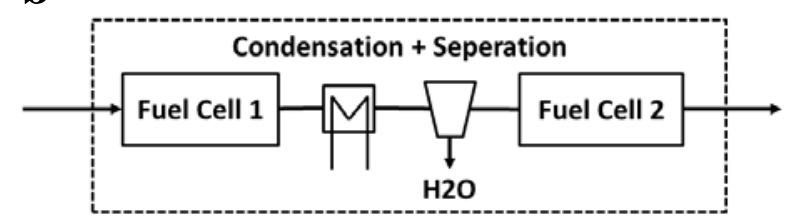

Fig. 1: (a) Single system architecture; (b) Twin system architecture (serial cathode including interim condensation)

The calculation of the relative humidity and the oxygen content of the cathode exhaust gas are based on Eq. 1 - 2 (fuel cell stack 1 - single or twin system) and Eq. 3 - 4 (fuel cell stack 2 - twin system).

$$
\begin{aligned}
& r H_{\text {Air } \text { Out }_{-} S 1}=\frac{2 \cdot p_{\text {Air_Out_S1 }_{-}}}{p_{\text {Sat }_{-} \mathrm{H}_{2} \mathrm{O}}\left(t_{S 1}\right) \cdot\left(\lambda_{S 1} \cdot \frac{1}{\chi_{\mathrm{O}_{2_{-} I n_{-} S 1}}}+1\right)} \cdot 100 \% \\
& C_{O_{2-} \text { Out }-S 1}=\frac{\lambda_{S 1}-1}{\lambda_{S 1} \cdot \frac{1}{\chi_{O_{2_{-} I_{-} S 1}}}-1} \cdot 100 \%
\end{aligned}
$$

The calculation of the relative humidity of fuel cell stack 2 in the twin system architecture considers the status of the 
interim condensation process (without condensation Eq. 3a - b/with condensation Eq. 3c-d).

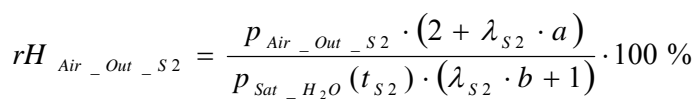

without interim condensation process:

$$
\begin{aligned}
& a=\frac{p_{H_{2} \mathrm{O}_{-} \mathrm{Out} \_\mathrm{S} 1}}{p_{\mathrm{O}_{2} \text { Out_S1 }}}=\frac{2+\lambda_{S 1} \cdot \frac{\chi_{\mathrm{H}_{2} \mathrm{O}_{-} I n_{-} S}}{\chi_{\mathrm{O}_{2} \text { In_S }}}}{\lambda_{S 1}-1} \\
& b=\frac{p_{\text {Air_out_S1 }}}{p_{\mathrm{O}_{2} \text { Out_S1 }}}=\frac{\lambda_{S 1} \cdot \frac{1}{\chi_{\mathrm{O}_{2} \text { In_S }}}+1}{\lambda_{S 1}-1}
\end{aligned}
$$

with interim condensation process:

$$
\begin{aligned}
& a=\frac{p_{\mathrm{H}_{2} \mathrm{O}_{-} \mathrm{Out}_{-} \mathrm{C}}}{p_{\mathrm{O}_{2} \mathrm{Out}_{-} \mathrm{C}}} \\
& b=\frac{p_{\text {Air_out } \_C}}{p_{\mathrm{O}_{2} \text { Out_C }}} \\
& C_{\mathrm{O}_{2} \text { Out }_{-} \mathrm{S} 2}=\frac{\lambda_{\mathrm{S} 2}-1}{\frac{\lambda_{\mathrm{S} 2} \cdot\left(\frac{\lambda_{S 1}}{\chi_{\mathrm{O}_{2} \text { In_S1 }}}-1\right)}{\lambda_{\mathrm{S} 1}-1}-1} \cdot 100 \%
\end{aligned}
$$

In the equations mentioned above, the subscripts $S 1$ denotes fuel cell stack 1, S2 denotes fuel cell stack 2, $C$ denotes the condensation and separation system. $r H_{\text {Air_out }}$ denotes the relative humidity of the cathode exhaust gas of the specified fuel cell, $C_{O 2 \_O u t}$ denotes the oxygen concentration inside the cathode exhaust air of the specified fuel cell, $\chi_{02 \_I n}$ denotes the substance amount fraction of oxygen inside the cathode feed stream of the specified fuel cell, $\chi_{\text {H2O_In }}$ denotes the substance amount fraction of water inside the cathode feed stream of the specified fuel cell, $\lambda$ denotes the cathode stoichiometric ratio of the specified fuel cell, $p_{\text {Air_out }}$ denotes the pressure of the cathode exhaust gas at the output of the specified component, $p_{\text {H2O_Out }}$ denotes the partial pressure of water in the cathode exhaust gas at the output of the specified component, $p_{O 2 \_ \text {Out }}$ denotes the partial pressure of oxygen in the cathode exhaust gas at the output of the specified component, $p_{\text {Sat_H2O denotes the }}$ temperature dependent saturation pressure of water vapor and $t$ denotes the average stack temperature.

The process simulation considers the following assumptions:
- differences between stack temperature and exhaust gas temperature at fuel cell outlet as well as stack temperature and cooling temperature at stack outlet are neglected

- temperature variations between the single cells within the fuel cell stack are neglected

- the inlet air at fuel cell stack 1 is not humidified $(\mathrm{rH}=$ $0 \%$ ), neither at the single system nor at the twin system

- the temperature and partial pressure of water in the inlet air at fuel cell stack 2 is adjustable by means of the condenser temperature

- load-dependent water diffusion (electro osmotic drag of water) from anode to cathode and water back diffusion from cathode to anode are neglected

- only isobaric processes inside the fuel cell systems, without operating pressure differences between stack inlet and stack outlet are considered

\subsection{Experimental Setup}

A test facility for measurements under low pressure conditions $\left(\mathrm{p} \leq \mathrm{p}_{\mathrm{amb}}\right)$ designed and assembled by the German Aerospace Center, Institute of Engineering Thermodynamics is applied for the experimentation. This test facility includes a single fuel cell system (PEMFC) to be tested at variable stack temperatures, operating pressures and stoichiometric ratios. The PEMFC system (HyPM XR 12) consists of 60 cells with an active total surface of 496 $\mathrm{cm}^{2}$. The cells include multi-meander flow fields and a Nafion ${ }^{\circledR}$ membrane with a catalyst load of $0.3 \mathrm{mg} \mathrm{Pt} / \mathrm{cm}^{2}$. The PEMFC system achieves a rated power of $12 \mathrm{~kW}$, a maximal output current of $350 \mathrm{~A}$ and an output voltage range of $30-60 \mathrm{~V}$. The test facility is applicable for operating temperatures of $10{ }^{\circ} \mathrm{C}-70^{\circ} \mathrm{C}$, absolute operating pressures of 200 mbar - $p_{a m b}$ and feed gas mass flows of $\leq 2500$ slpm (cathode) or $25 \mathrm{slpm}$ (anode purge), respectively. In addition, the test facility possesses an electric capacity of 25 $\mathrm{kW}$ and a cooling capacity of $30 \mathrm{~kW}$. A pressure control between anode and cathode ensures a permanently minor pressure difference. This experimental setup represents the single system architecture discussed. Fig. 5 (Appendix) demonstrates the principle process scheme including the PEMFC system and subcomponents.

A statistical test planning and evaluation defining the matrix of inlet parameters variations for experimentation is the basis of the experimental investigations. The experiments aim at validation and verification of the modelling and simulation of the single system architecture with regard to the relative humidity of the cathode exhaust gas, a key factor of an adequate water management, affecting the 
average cell efficiency of the multifunctional PEMFC system [3].

The experimental results discussed in section 3 represent measurements at varying pressure and cooling temperature levels at stack outlet with reference to the cathode stoichiometric ratio $\lambda=2.1$ and the load requirement (electric current) $\mathrm{I}=300$ A. Further measurements of PEMFC operation (single system architecture) at the low pressure test facility described are provided in [12].

\section{Results and discussion}

The following discussion aims at the impact of the operating parameters (stack temperature, operating pressure and cathode stoichiometric ratio) on the relative humidity and oxygen content of the cathode exhaust gas as well as on the efficiency and stability, consequently.

The relative humidity and oxygen content of the cathode exhaust gas are defined in Eq. 1 - 4. The efficiency (average fuel cell efficiency) as described in Eq. 5 depends on the average stack voltage $\mathrm{U}$, the existing number of cells $\mathrm{n}$ and the reversible cell voltage $\mathrm{U}_{0}[16]$.

$\eta_{U}=\frac{U}{n \cdot U_{0}}$

The reversible cell voltage $\mathrm{U}_{0}$ is affected by the variation of the Gibbs free enthalpy $\Delta \mathrm{G}^{0}$ or the variation of the enthalpy of formation $\Delta \mathrm{H}^{0}$ and the product of temperature and variation of the reaction entropy $\Delta S^{0}$ as well as the number of electrons $\mathrm{z}$ in the redox reaction and the Faraday constant F (Eq. 6).

$U_{0}=-\frac{\left(\Delta G^{0}\right)}{z F}=-\frac{\left(\Delta H^{0}-T \Delta S^{0}\right)}{z F}$

The stability in fuel cell system operation depends on voltage drops of single cells. A voltage drop of single cells registered by the fuel cell controller triggers a system shutdown and results in a non-steady measuring point.

\subsection{Analysis of the single system architecture}

Due to the electrochemical reactions at the membrane electrode assembly (MEA), an oxygen decrease along the cathode gas channels of air fed PEMFC systems is expected. The resulting oxygen concentration of dry cathode exhaust gas at varying stoichiometric ratios (cathode) is illustrated in Fig. 2a. The recommended stoichiometric ratio of $\lambda_{\mathrm{S} 1}=$
$2.5^{1}$ in PEMFC operation of the single system architecture result in an oxygen concentration of 13.8 Vol.-\% (Fig. 2a Example 1). An oxygen concentration of $\leq 12$ Vol.- $\%$ is required to use oxygen depleted air for inerting purposes and/or fire suppression and fire fighting in aviation [13]. When adjusting the stoichiometric ratio to $\lambda_{\mathrm{S} 1}=1.9$ in PEMFC operation (single system architecture), a decrease in oxygen concentration to $<12 \mathrm{Vol} .-\%$ is achievable, according to Fig. 2a (Example 2). Accordingly, on the one hand a modification of the cathode stoichiometric ratio is required to adjust the oxygen content of the cathode exhaust gas. On the other hand a modification of the cathode stoichiometric ratio impacts the relative humidity of the cathode exhaust gas.

Except from the cathode stoichiometric ratio, the relative humidity of the cathode exhaust gas is also affected by the operating parameters pressure and stack temperature (Fig. 2b). The simulation results demonstrated are related to the operating pressures 200 mbar, 700 mbar, 950 mbar as well as 2000 mbar representing emergency operation (cabin decompression), cruise (cabin pressure at altitude levels $>$ $3000 \mathrm{~m}$ ), ambient pressure operation (cabin pressure in ground operation) and pressurized operation of PEMFC systems in aviation. The stack temperatures $40-60{ }^{\circ} \mathrm{C}$ highlighted in Fig. 2b correspond to the manufacturer's data recommended for the operation of the HyPM XR 12 system [14]. The calculated relative humidity values in this study are average values at stack outlet based on average stack temperatures. Thus, the temperature distribution across the stack assembly according to [17] (the temperature decreases from the inner to the outer cells of a stack) resulting in variations of the relative humidity at the outlet of the single cells in relation to the spatial position of the cells within the stack is not considered.

A high-performing and steady PEMFC operation requires an adequate water management, to be ensured by controlling the relative humidity of the cathode exhaust gas in the range of $90-110 \%[10,11]$ shown in Fig. $2 b$.

According to the process simulation considering the recommended manufacturer's data (stack temperature requirements), the PEMFC operation at a cathode stoichiometric ratio of $\lambda_{\mathrm{S} 1}=2.5$ and operating pressures of 700 mbar or 950 mbar is performable due to the resulting adequate relative humidity of the cathode exhaust gas (Fig.

${ }^{1}$ The stoichiometric ratio of $\lambda=2.5$ is related to load requirements (electric current) of 175 - $350 \mathrm{~A}$, corresponding to the factory setting of the PEMFC system HyPM XR 12 . 
$2 \mathrm{~b}$ - Example 1). The PEMFC operation at a cathode stoichiometric ratio of $\lambda_{\mathrm{S} 1}=2.5$ and operating pressures of $200 \mathrm{mbar}$ or $2000 \mathrm{mbar}$ is to be avoided, because of the undue stack temperatures required to achieve a relative humidity of the cathode exhaust gas in the range of 90 $110 \%$, ensuring an adequate water management. According to the process simulation a relative humidity $\mathrm{rH}=42 \%$ is expected at 200 mbar and the minimal permitted average stack temperature of $40^{\circ} \mathrm{C}$ resulting in membrane dehydration. A relative humidity $\mathrm{rH}=156 \%$ and fuel cell flooding is expected at 2000 mbar and the maximal permitted average stack temperature of $60{ }^{\circ} \mathrm{C}$ (Fig. $2 \mathrm{~b}$ Example 1).

At a cathode stoichiometric ratio of $\lambda_{\mathrm{S} 1}=1.9$ (Fig. $2 \mathrm{~b}$ Example 2) the acceptable operating pressure is limited to 700 mbar or 950 mbar, as a consequence of the undue resulting stack temperature required for an adequate water management at 200 mbar or 2000 mbar.

Due to the calculated relative humidity $\mathrm{rH}=54 \%$ and the expected membrane dehydration, the PEMFC operation of a self-humidified single fuel cell system should be excluded at an operating pressure of 200 mbar. A relative humidity $\mathrm{rH}=200 \%$ and fuel cell flooding is expected at $2000 \mathrm{mbar}$ and the maximal permitted average stack temperature of $60{ }^{\circ} \mathrm{C}$ (Fig. 2b - Example 2).
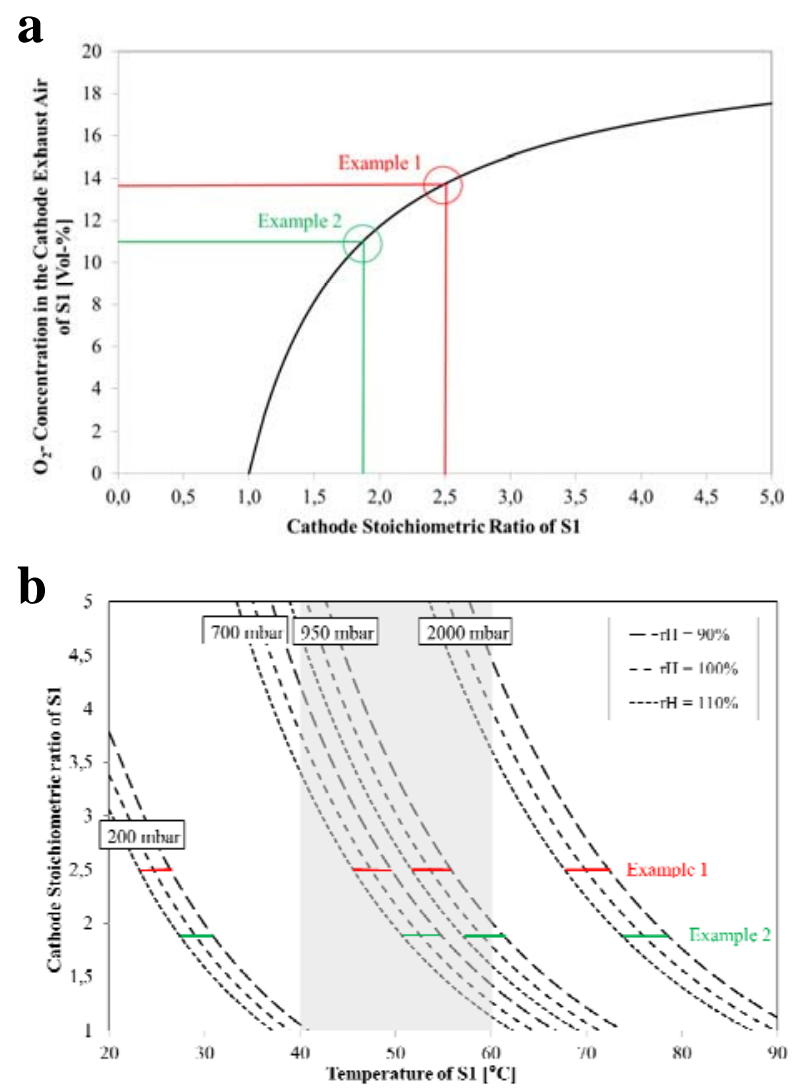

Fig. 2: (a) Oxygen concentration of dry exhaust gas (cathode) at varying cathode stoichiometric ratios (basis: single system architecture); (b) Correlation between operating pressure, stack temperature, cathode stoichiometric ratio and relative humidity (basis: single system architecture)

Options to set the relative humidity between $90-110 \%$ within the recommended stack temperature range (40 $60{ }^{\circ} \mathrm{C}$ ) are related to feed gas humidification at $\mathrm{p}=200$ mbar (single system architecture). An operation of the single system architecture at $2000 \mathrm{mbar}$ is not to be realized under the conditions specified. Previous studies [9, 11] prove these results regarding the impact of the operating parameters on the water management of PEMFC systems. Lower stack temperatures and/or lower cathode stoichiometric ratios result in increased relative humidity of the cathode exhaust gas and increased membrane conductivity, according to $[9,11]$. Moreover, operating pressure variations affect the relative humidity of the cathode exhaust gas as well [11]. 
a

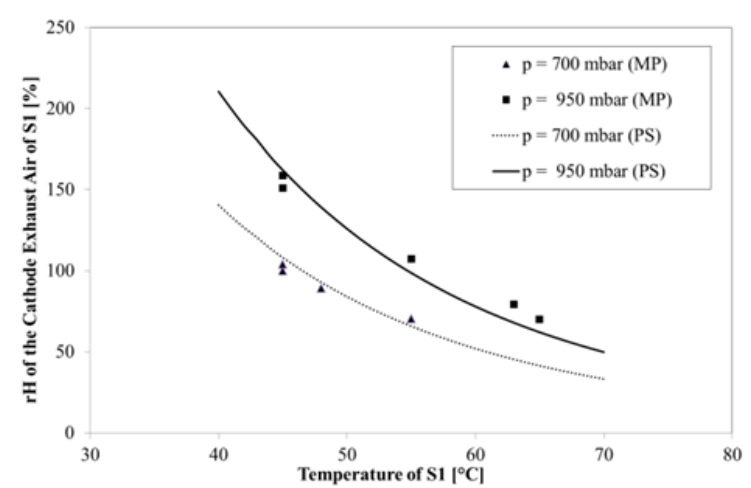

b

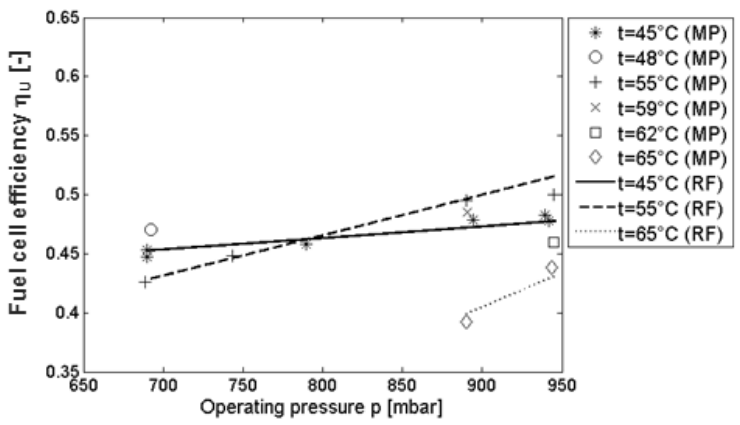

Fig. 3: (a) Relative humidity at varying stack temperatures (reference: $\lambda_{\mathrm{S} 1}=2.1 ; \mathrm{I}=300 \mathrm{~A}$ ); MP: measuring point; PS: process simulation; (b) Average fuel cell efficiency at varying operating pressures and cooling temperatures at stack outlet (reference: $\lambda_{\mathrm{S} 1}=2.1$; I $=300 \mathrm{~A}$ ); MP: steady measuring point; RF: regression function [12]

The experimental work and validation of the process simulation is presented in the following subsection. Fig. 3a illustrates the relative humidity at varying stack temperatures and proves the correlation between process simulation (PS) and measuring points (MP) $)^{2}$ for experiments at 700 mbar and 950 mbar (reference: $\lambda_{\mathrm{S} 1}=2.1$; I $=300 \mathrm{~A}$ ). According to Fig. 3a, a decrease of the relative humidity is ascertainable at lower operating pressure and higher stack temperature. These effects result from the increasing water absorbing capacity of air at decreasing operating pressure and increasing stack temperature, as described in [11].

2 The calculation of the relative humidity of the cathode exhaust gas in Fig. 3a is based on the humidity registered downstream the condenser, the water quantity segregated by the cyclone separator as well as the operating pressure and temperature measured at stack output during the experimentation.
Fig. $3 \mathrm{~b}$ represents the impact of the operating pressure and the cooling temperature at stack outlet on fuel cell efficiency as discussed in [15]. Steady measuring points (MP) and corresponding regression functions (RF) of the fuel cell efficiency at varying operating pressures and cooling temperatures at stack outlet are shown in Fig. 3b. A variation of the operating pressure from 950 mbar to 700 mbar results in a decrease of the average fuel cell efficiency of $5.3-16.6 \%$ depending on the cooling temperature at stack outlet [12]. The optimal pressure-dependent efficiency is achievable by setting the cooling temperature at stack outlet, according to Fig. 3b. A decrease in operating pressure tends to result in decreased cooling temperatures at stack outlet required, due the increasing evaporation rates affecting the water management and the cell voltage consequently. The regression functions of the efficiency in Fig. $3 b$ prove the optimal cooling temperature at stack outlet $\mathrm{t}=45^{\circ} \mathrm{C}$ for $\mathrm{p}=700$ mbar and $\mathrm{t}=55^{\circ} \mathrm{C}$ for $\mathrm{p}=950$ mbar.

The pressure-dependent optimal cooling temperatures at stack outlet examined in the experiments correlate with the calculated relative humidity of the cathode exhaust gas for the different points of operation, summarized in Tab. 1 . Accordingly, the operating pressure of $950 \mathrm{mbar}$ and the cooling temperature at stack outlet of $55{ }^{\circ} \mathrm{C}$ result in a relative humidity of $98 \%$. The operating pressure of 700 mbar and the cooling temperature at stack outlet of $45{ }^{\circ} \mathrm{C}$ result in a relative humidity of $108 \%$.

Tab. 1: Relative humidity of the cathode exhaust gas calculated for selected cooling temperatures at stack outlet and operating pressures

\begin{tabular}{lcc}
\hline Temperature & rH for 950 mbar & rH for $700 \mathrm{mbar}$ \\
\hline $45^{\circ} \mathrm{C}$ & $161 \%$ & $108 \%$ \\
$55^{\circ} \mathrm{C}$ & $98 \%$ & $65 \%$ \\
$65{ }^{\circ} \mathrm{C}$ & $62 \%$ & $41 \%$ \\
\hline
\end{tabular}

Therewith, the significance of the cathode exhaust gas humidity range defined for a high-performing and steady fuel cell operation $[10-11]$ is confirmed by process simulation and experiments. Furthermore, the relevance of the process simulation developed to optimize the control strategy of a fuel cell system to be applied at varying environmental conditions in aviation is proven.

However, the specification regarding the oxygen concentration of $\leq 12$ Vol.- $\%$ required for inerting purposes [13] is not to be realized in the present fuel cell experiments implementing a cathode stoichiometric ratio $\lambda_{\mathrm{S} 1}=2.1$ (cp. Fig. 2a). Thus, further experiments focusing on variations 
of the cathode stoichiometric ratio are recommended, in order to validate and verify the simulation results of the single system architecture with regard to the generation of oxygen depleted air, especially.

\subsection{Analysis of the twin system architecture}

This section seizes on the present insights with regard to the water management of a multifunctional PEMFC system discussed for the single system architecture, which is not feasible at an operating pressure $p=2000$ mbar due to the resulting fuel cell flooding. Therefore, a special case representing the continuation of this previous investigation is described in section 3.2. It is focused on the twin system architecture according to Fig. 1b. The following simulation process aims at the pressurized operation of this twin system architecture considering a dehumidification process to control the water management of fuel cell stack 2 , in particular.

The inlet air at fuel cell stack 1 is not humidified $(\mathrm{rH}=0 \%)$. An operating pressure of $p=2000$ mbar is used to exemplify the PEMFC operation of the twin system. In order to meet the stack temperature requirement $\left(\mathrm{t} \leq 60{ }^{\circ} \mathrm{C}\right)$ illustrated in Fig. 2b, a cathode stoichiometric ratio at stack 1 of $\lambda_{\mathrm{S} 1}=3.6$ is defined. At $t_{\mathrm{S} 1}=60{ }^{\circ} \mathrm{C}$ and $\lambda_{\mathrm{S} 1}=3.6$, the relative humidity of the cathode exhaust gas of fuel cell 1 is about $110 \%$, the upper boundary of the optimal relative humidity range (cp. Fig. 2b). The inlet air at fuel cell stack 2 is conditioned, after the interim condensation process (condensation temperature $10^{\circ} \mathrm{C}$ ).

In Fig. 4a, the oxygen concentration of the twin system exhaust gas at a constant cathode stoichiometric ratio of $\lambda_{\mathrm{S} 1}$ $=3.6$ at fuel cell stack 1 and varying cathode stoichiometric ratios at fuel cell stack 2 is represented. A depletion of the oxygen concentration $\mathrm{C}_{\mathrm{O} 2 \text { _out_S2 }} \leq 12$ Vol.- $\%$ to achieve ODA specifications is feasible at cathode stoichiometric ratios of $\lambda_{\mathrm{S} 1} \leq 3.6$ at fuel cell stack 1 and $\lambda_{\mathrm{S} 2} \leq 2.8$ at fuel cell stack 2 (Fig. 4a - Example 3). Accordingly, the twin system architecture enables equivalent oxygen depletion rates at increased cathode stoichiometric ratios (compared to the single system architecture), cp. Fig. 3a and Fig. 4a. Consequently, extended options for inerting result from the operation of the twin system architecture.

Since fuel cell stack 2 is supplied by the exhaust gas of fuel cell stack 1, the cathode stoichiometric ratio of fuel cell stack 2 depends on the cathode stoichiometric ratio of fuel cell stack 1 and the load ratio between fuel cell stack 1 and 2, described in Eq. 7.
$\frac{I_{S 1} \cdot Z_{S 1}}{I_{S 2} \cdot Z_{S 2}}=\frac{\lambda_{S 2}}{\lambda_{S 1}-1}$

In Eq. 7 the subscript $S 1$ denotes fuel cell stack 1, S2 denotes fuel cell stack 2 . I denotes the electric current, $\mathrm{z}$ the number of cells and $\lambda$ the cathode stoichiometric ratio of the fuel cell system specified.

The cathode stoichiometric ratios of $\lambda_{\mathrm{S} 1}=3.6$ (fuel cell stack 1) and $\lambda_{\mathrm{S} 2}=2.8$ (fuel cell stack 2) in Fig. 4 - Example 3 are related to a load requirement ratio of $\mathrm{I}_{\mathrm{S} 1} \mathrm{z}_{\mathrm{S} 1} / \mathrm{I}_{\mathrm{S} 2} \mathrm{Z}_{\mathrm{S} 2}=$ 1.1. That means, these settings of the cathode stoichiometric ratios require higher loads provided by fuel cell stack 1 compared to fuel cell stack 2, when using stacks of the same size (same number of cells).

The calculated relative humidity of the cathode exhaust gas at fuel cell stack 2 in the twin system architecture discussed is related to the cathode stoichiometric ratios $\lambda_{\mathrm{S} 1}$ and $\lambda_{\mathrm{S} 2}$ and the stack temperature of fuel cell stack 2 . The options with/without interim condensation are distinguished in Fig. $4 \mathrm{~b}$.

Due to the application of the interim condensation, there is a temperature shift at fuel cell stack 2 determinable for the resulting relative humidity of the cathode exhaust gas. That means the required temperature of fuel cell stack 2 is 74 $79{ }^{\circ} \mathrm{C}$ (without interim condensation) and $61-65^{\circ} \mathrm{C}$ (with interim condensation) to achieve the relative humidity $90 \%$ $\leq \mathrm{rH} \leq 110 \%$ (Fig. $4 \mathrm{~b}$ - Example 3). The operation of fuel cell stack 2 exactly adapted to the defined manufacturer's stack temperature $\left(40-60{ }^{\circ} \mathrm{C}\right)$ and the relative humidity $(90$ - $110 \%$ ) cannot be realized according to Fig. 4b, neither without interim condensation nor with interim condensation. However, measurements presented in [12] prove the stability of HyPM XR 12 systems for operation at cooling temperatures at stack outlet above $60{ }^{\circ} \mathrm{C}$. 


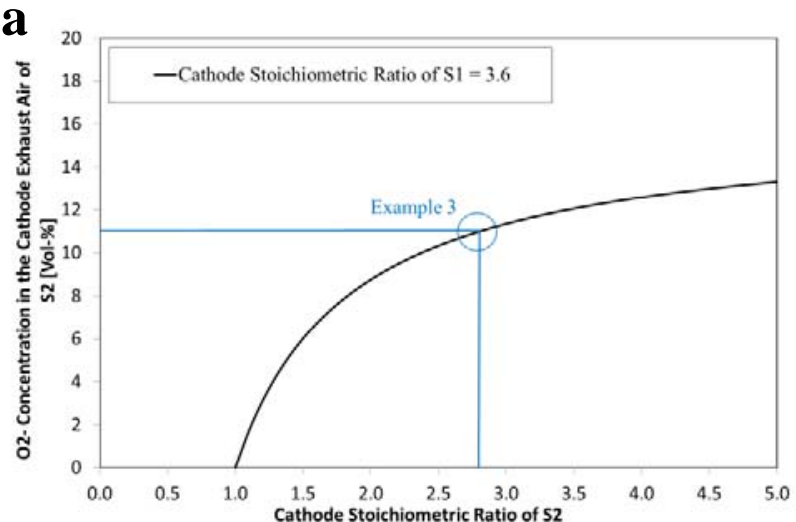

b

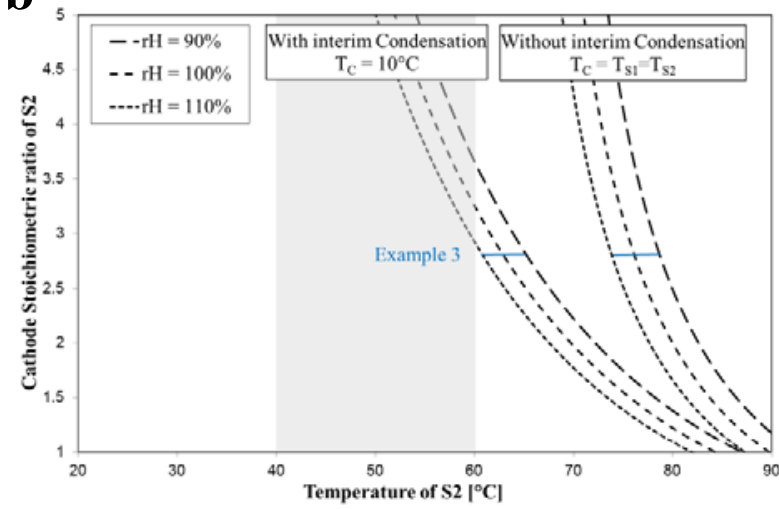

Fig. 4: (a) Oxygen concentration of the twin system exhaust gas at varying cathode stoichiometric ratios at fuel cell stack 2 (reference: cathode stoichiometric ratio at stack 1 $\lambda_{\mathrm{S} 1}=3.6$ ); (b) Correlation between stack temperature, cathode stoichiometric ratio and relative humidity of the cathode exhaust gas at fuel cell stack 2 with and without interim condensation at 2000 mbar (basis: twin system architecture)

Summing up the process simulation, the twin system architecture results in extended options for inerting purposes. Higher stoichiometric ratios within the twin system architecture refer to equivalent oxygen depletion rates compared to the single system architecture. Therefore the authors claim that the twin system architecture enables the generation of oxygen depleted air with lower oxygen concentration compared to the single system architecture. Furthermore, the production of oxygen depleted air for inerting purposes at the pressurized operation, close to the manufactures stack temperature range becomes feasible with the twin system architecture including an interim condensation. Due to the interim condensation fuel cell flooding can be minimized with the twin system at pressurized operation.

Experimental investigations of the twin system architecture are recommended to characterize the efficiency and stability depending on the operating parameters discussed and to validate the results of the process simulation.

\section{Conclusion and Outlook}

This paper characterizes operating parameters and system architectures in terms of the water management of a multifunctional PEMFC system to be applied in aviation applications. This analysis is based on process simulation and experiments. The process simulation considers single and highly innovative twin system architectures. The experiments are focused on the single system architecture. The results achieved are used to identify operation and architecture improvements for an appropriate water management, a key aspect to optimize efficiency and stability of PEMFC systems [1]. Based on the present process simulation and experimental investigations can be summarized:

- The stack temperature and/or the cathode stoichiometric ratio have to be increased at increasing pressure to avoid fuel cell flooding.

- The stack temperature and/or the cathode stoichiometric ratio have to be decreased at decreasing pressure to avoid membrane dehydration.

- Especially at low pressure operation an additional feed gas humidification could be appropriate to meet the defined manufacturer's stack temperature range (40 $\left.60{ }^{\circ} \mathrm{C}\right)$.

- Within the defined manufacturer's stack temperature range $\left(40-60{ }^{\circ} \mathrm{C}\right)$, the twin system architecture is relevant to minimize fuel cell flooding at high pressure.

- The twin system architecture enables equivalent oxygen depletion rates at increased cathode stoichiometric ratios (compared to the single system architecture).

These results confirm the working hypothesis of the authors as well as previous studies on the effects of operating parameters on the resulting relative humidity of the cathode exhaust gas and consequently on the efficiency of PEMFC systems $[8,9,11]$. Further research activities planned on the water management in multifunctional fuel cell operation refer to:

- experimental studies on self-humidified PEMFC systems to be operated in stack temperature ranges beyond the manufacturer's conditions, e. g. $\mathrm{t} \leq 40{ }^{\circ} \mathrm{C}$ or $\mathrm{t} \geq 60{ }^{\circ} \mathrm{C}$ to prove the low and high pressure operation of the HyPM XR 12 system (cp. Fig. 2b, 4b) and to optimize the control strategy of the fuel cell system to be applied at varying environmental conditions in aviation,

- experimental verification and validation of the process simulation (twin system architecture) to demonstrate the 
high-performing and steady PEMFC operation including the appropriate water management at high pressure levels as well as the expected depletion of oxygen concentration in the exhaust gas,

- advanced studies on feasibility limits with respect to further depletion of oxygen concentration in the exhaust gas of twin system architecture for fire suppression or firefighting purposes,

- investigation on temperature variations between the single cells inside the fuel cell stack and the influence on the water management of the system,

- further investigations on multiple fuel cell architectures considering asymmetrical system designs (sizes and/or types) to prove the adequacy for a multifunctional application in aviation.

\section{Acknowledgements}

The work presented is part of the research project „, Fuel Cell and Hydrogen Systems - FUCHS“ (project number: 20Y1105B) supported by the Federal Ministry of Economic Affairs and Energy. The authors gratefully acknowledge the support received. In addition, the authors acknowledge the contribution of their colleagues Florian Gores (DLR/TT) and Gunnar Preiß (DLR/TT).

\section{REFERENCES}

[1] Ji, M. and Wei, Z., "A Review of Water Management in Polymer Electrolyte Membrane Fuel Cells", Energies Vol. 2, 2009, pp. 1057-1106.

[2] ACARE (eds.): European Aeronautics: A vision for 2020, In: www.acare4europe.org/sites/acare4europe. org /files/document/Vision\%202020_0.pdf (2001)

[3] Jiao,Q.; Li, X.: Water transport in polymer electrolyte membrane fuel cells, Progress in Energy and Combustion Science, Volume 37, Issue 3, 2011, pp. 221-291

[4] Vengatesan, S.; Kim, H.J.; Cho, E.A.; Jeong, S.; Ha, H.; Oh, I.; Hong, S. and Lim, T.: Operation of a proton-exchange membrane fuel cell under nonhumidified conditions using thin cast Nafion membranes with different gas-diffusion media, Journal of Power Sources, Volume 156, Issue 2, 2006, pp. 294-299

[5] Dai, W.; Wang, H.; Yuan, X.-Z.; Martin, J.; Yang, D.; Qiao, J.; Ma, J.: A review on water balance in the membrane electrode assembly of proton exchange membrane fuel cells, International Journal of Hydrogen Energy, Volume 34, Issue 23, 2009, pp. 9461-9478

[6] Wilkinson, D.; St-Pierre, J.: In-plane gradients in fuel cell structure and conditions for higher performance, Journal of Power Sources, Volume 113, Issue 1, 01/2003, pp. 101-108

[7] Yang, T.; Shi, P.; Du, C.: Study on self-humidified PEMFC with reactant circulation, Electrochimica Acta, Volume 51, Issue 26, 2006, pp. 5618-5625

[8] Picot, D.; Metkemeijer, R.; Bezian, J.J.; Rouveyre, L.: Impact of the water symmetry factor on humidification and cooling strategies for PEM fuel cell stacks, Journal of Power Sources, Volume 75, Issue 2, 1998, pp. 251-260

[9] Chan, S.H.; Xia, Z.T; Wei, Z.D.: Matching of critical parameters in a small non-pressurized non-humidified PEMFC stack, Journal of Power Sources, Volume 158, Issue 1, 2006, pp. 385-391

[10] Tolj, I.; Bezmalinovic, D.; Barbir, F.: Maintaining desired level of relative humidity throughout a fuel cell with spatially variable heat removal rates, International Journal of Hydrogen Energy, Volume 36, Issue 20, 2011, pp. 13105-13113

[11] Larminie, J.; Dicks, A.: Fuel Cell Systems Explained $2^{\text {nd }}$ Edition, Wiley, 2003, ISBN: 978-0-470-84857-9

[12] Werner, C.; Gores, F.; Busemeyer, L.; Kallo, J.; Heitmann, S.; Griebenow, M.: Characteristics of PEMFC operation in ambient- and low-pressure environment considering the fuel cell humidification, CEAS Aeronautical Journal, 2014, DOI: 10.1007/ s13272-014-0142-z.

[13] European Aviation Safety Agency (ed.): Certification specification for large aeroplanes CS-25, In: http://www. easa.europa.eu, 2010.

[14] HyPM XR 12 Installation and Operation Manual, Version 1.0, Hydrogenics Corp, Canada, 2007

[15] Pratt, J. W.; Brouwer, J.; Samuelson, G. S.: Performance of proton exchange membrane fuel cell at high-altitude conditions, Journal of Propulsion and Power, Vol. 23, No. 2, March-April 2007

[16] Kurzweil, P.: Brennstoffzellentechnik-Grundlagen, Komponenten, Systeme, Anwendungen. Friedr. Vieweg und Sohn Verlag/GWV Fachverlag GmbH, Wiesbaden , 2003.

[17] Shimpalee, S.; Ohashi, M.; Van Zee, J. W.; Ziegler, C.; Stoeckmann, C.; Sadeler, C.; Hebling, C.: Experimental and numerical studies of portable PEMFC stack, Electrochemical Acta, 2008, DOI: 10.1016/ j.electacta.2008.11.008 


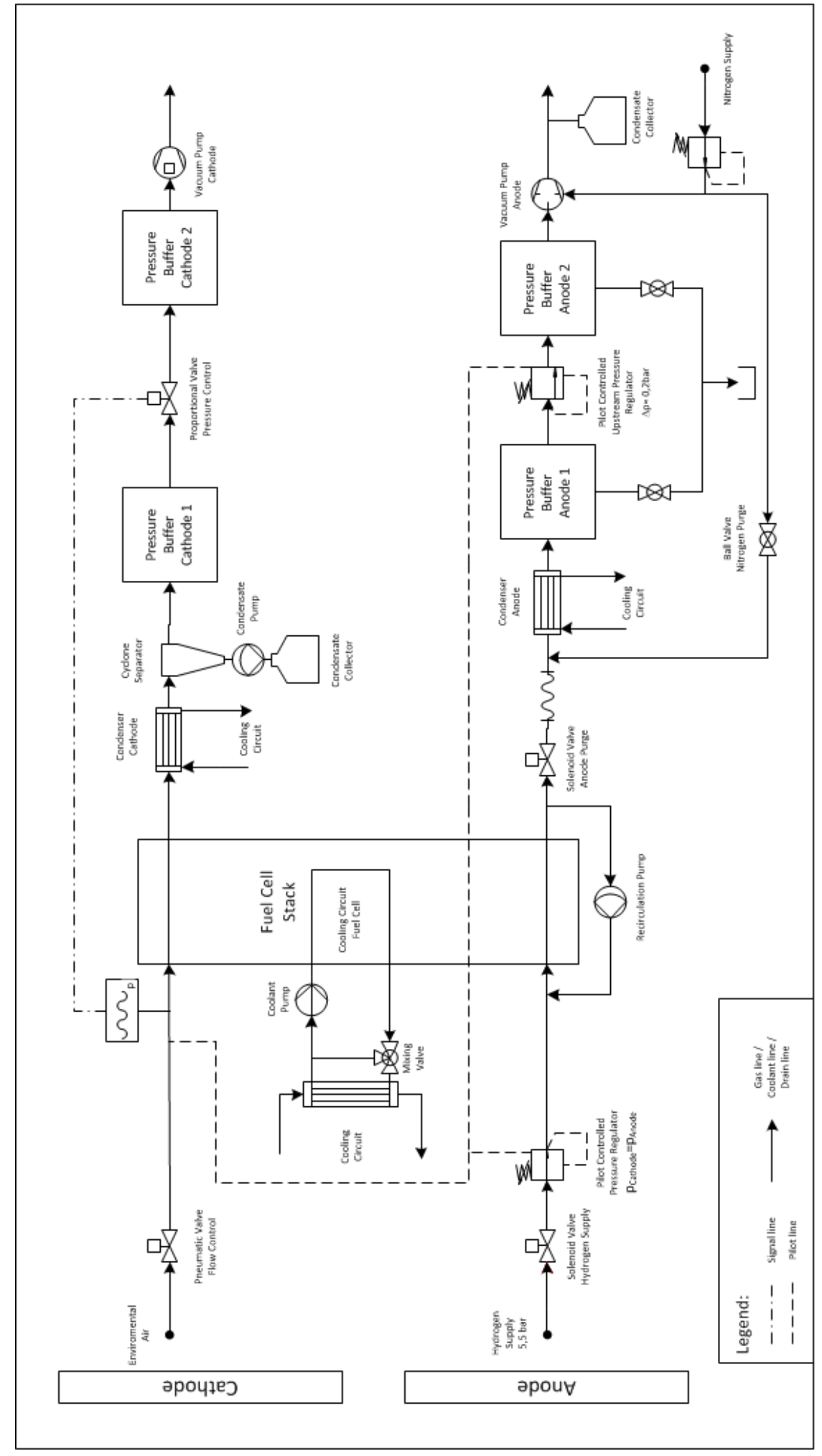

Fig. 5: Principle process scheme of the test facility for PEMFC designed and assembled by the German Aerospace Center, Institute of Engineering Thermodynamics [12]. 